\title{
Nutritional and microbiological quality of bovine colostrum samples in Brazil
}

\author{
Glauber dos Santos ${ }^{1}$, Jackeline Thaís da Silva ${ }^{1}$, Flávia Hermelina da Rocha Santos ${ }^{1}$, Carla \\ Maris Machado Bittar ${ }^{* *}$
}

${ }^{1}$ Universidade de São Paulo, Escola Superior de Agricultura "Luiz de Queiroz", Departamento de Zootecnia, Piracicaba, SP, Brazil.

ABSTRACT - The objective of this study was to evaluate the nutritional and microbiological composition of colostrum samples collected from colostrum banks or newly calved cows on dairy farms. For this purpose, 66 colostrum samples from dairy cows were directly collected during the milking of newly calved cows or from colostrum storage bank. Samples were collected from commercial properties in the states of Minas Gerais, São Paulo, and Paraná - Brazil, which were classified according to the total daily milk yield (MY). Even though average immunoglobulin concentrations were either adequate $(79.7$ and $51.7 \mathrm{mg} / \mathrm{mL}$, for farms with $\mathrm{MY}>701 \mathrm{~L} / \mathrm{d}$ and $<200 \mathrm{~L} / \mathrm{d}$, respectively) or marginal $(48.1 \mathrm{mg} / \mathrm{mL}$ for MY between 201-700 L/d), for only $48.4 \%$ of the colostrum samples, immunoglobulin concentrations were greater than $50 \mathrm{mg} / \mathrm{mL}$. A variety of factors such as production system, animal breed, and time of sample collection can also affect the variables studied. In addition to emphasizing nutrition, good hygiene practices during the colostrum collection and storage process also deserve attention, since $24 \%$ of colostrum samples were below the microbial quality parameters. When nutritional and microbiological quality were simultaneously analyzed, only $22.6 \%$ of colostrum samples met the recommendations. Therefore, most of the calves in this region of Brazil are likely to present failure of passive immunity transfer and are exposed to pathogens when fed maternal colostrum.

Key Words: dairy calf, enterobacteria, immunoglobulin G, passive immunity transfer

\section{Introduction}

Due to physiological characteristics of bovines, the supply of antibodies via colostrum during the first hours of life becomes fundamental to newborn survival (Weaver et al., 2000). The serum concentration of immunoglobulin $\mathrm{G}$ (IgG) that is desired for calves within the first $24 \mathrm{~h}$ of life is greater than $10 \mathrm{~g} / \mathrm{L}$ (Godden, 2008), which is determined by colostrum IgG concentration, the time of intake, and the volume of consumed colostrum. Adequate transfer of passive immunity has a positive correlation with a reduction in morbidity and mortality during the pre- and post-weaning periods (Wells et al., 1996), an improvement in weight gain and feed efficiency (Donovan et al., 1998), a reduction in the age at first calving, and an increase in the

Received: May 4, 2016

Accepted: September 17, 2016

*Corresponding author: carlabittar@usp.br

http://dx.doi.org/10.1590/S1806-92902017000100011

How to cite: Santos, G.; Silva, J. T.; Santos, F. H. R. and Bittar, C. M. M. 2017. Nutritional and microbiological quality of bovine colostrum samples in Brazil. Revista Brasileira de Zootecnia 46(1):72-79.

Copyright (C) 2017 Sociedade Brasileira de Zootecnia. This is an Open Access article distributed under the terms of the Creative Commons Attribution License (http://creativecommons.org/licenses/by/4.0/), which permits unrestricted use, distribution, and reproduction in any medium, provided the original work is properly cited. milk yield during the first and second lactations (DeNise et al., 1989; Faber et al., 2005).

Besides the transfer of passive immunity, colostrum has other important functions such as providing nutrients for the metabolism of the newborn (NRC, 2001). Fat, the main energy source for newborns, represents approximately $6.7 \%$ of colostrum (Foley and Otterby, 1978) and is important for heat production and maintenance, as well as for providing fatty acids for glucose homeostasis via gluconeogenesis (Hammon et al., 2012). In addition to the lipid content, lactose, despite its low colostrum concentration (2.7\%), has also an important function in the energy supply of newborns (Davis and Drackely, 1998). Another group that contributes to good newborn development is non-immunoglobulin proteins, which facilitate nutrient absorption and provide amino acids for development of the gastrointestinal tract (Talukder et al., 2002).

Colostrum can be contaminated by microorganisms, which can reduce animal performance as well as increase morbidity and mortality rates (Godden, 2008; Stabel et al., 2004). These pathogens may originate from the mammary gland or contaminate the colostrum during collection, manipulation, and storage processes (Stewart et al., 2005). Moreover, bacteria can bind to free immunoglobulins in the intestinal lumen and block absorption of these molecules by enterocytes (James and Polan, 1978) or 
stimulate the standstill of pinocytosis activity in enterocytes (James et al., 1981).

Morrill et al. (2012) evaluated colostrum from different North American regions and concluded that only 39\% of samples had adequate IgG concentrations and ideal microbiological characteristics. Data in Brazil are scarce, and generally, evaluation of the quality of colostrum provided to newborns considers only the immunoglobulin (Ig) concentration, which is estimated using a colostrometer. The objective of this study was to evaluate the nutritional and microbiological composition of colostrum samples collected from a colostrum bank or newly calved cows that were supposed to feed newborn calves, on dairy farms in Brazil.

\section{Material and Methods}

Sixty-six colostrum samples were directly collected by milking newly calved cows or came from a colostrum bank, depending on the availability of colostrum when visiting properties between July and December of 2013. Samples were collected from commercial dairy farms in Minas Gerais (24), São Paulo (32), and Paraná states (10), Brazil. Paraná had the highest average production by lactating cow $(30.25 \mathrm{~kg})$ and daily production $(3,485$ $\mathrm{kg} /$ day) due to the feeding production system, specialized animals, and a more favorable climate with lower average temperature. São Paulo had the farm with the largest volume of daily production $(42,000 \mathrm{~L})$, but the average daily production was $1,895 \mathrm{~L}$ and production per lactating cow was $18.30 \mathrm{~kg} /$ day. The maximum daily production per cow $(42.31 \mathrm{~kg})$ was observed in Minas Gerais, which presented the lowest average productivity $(14.11 \mathrm{~kg})$ and daily production $(1,085 \mathrm{~kg})$ due to utilization of non-specialized animals (crossbred zebu and Holstein cows) and a lack of feed supplementation in the majority of the properties.

In addition to classification by region, properties were classified according to their total daily milk yield (Table 1) into the following categories: small, when the milk yield was lower than $200 \mathrm{~L}$ ( $47 \%$ of the total evaluated farms); medium, when the milk yield was between 201 and $700 \mathrm{~L}$ ( $17 \%$ of the total evaluated farms); and large, when

Table 1 - Distribution of properties as a function of daily milk yield and region

\begin{tabular}{lcccc}
\hline & Minas Gerais & São Paulo & Paraná & All \\
\hline$<200 \mathrm{~L}$ & 12 & 19 & 0 & 31 \\
201 to $700 \mathrm{~L}$ & 8 & 3 & 0 & 11 \\
$>701 \mathrm{~L}$ & 4 & 10 & 10 & 24 \\
Total & 24 & 32 & 10 & 66 \\
\hline
\end{tabular}

the milk yield was greater than $701 \mathrm{~L}(36 \%$ of the total evaluated farms). In small farms, the feeding of lactating and pre-partum cows were based on grazing without supplementation and the animals were mostly crossbred Zebu $\times$ Holstein. On the other hand, farms classified as large had more than $90 \%$ of the Holstein animals in free-stalls, receiving total mixed ration (TMR) according to lactation phase. Pre-partum cows were also stabulated and fed a balanced TMR to meet their requirements for an average period of 60 to 80 days pre-partum.

Only one sample of colostrum was collected from each property and all samples were transported in a cooler box to a laboratory. At the laboratory, samples were frozen $\left(-20^{\circ} \mathrm{C}\right)$ to undergo further nutritional and microbiological (enterobacteria, lactic acid bacteria, fungi, and yeast) and chemical analyses (dry matter, lactose, fat, and total protein). Samples of colostrum obtained by milking newly calved cows were also frozen to simulate storage in a colostrum bank for further newborn calf feeding, since this is done in most of the visited farms. In this manner, all samples were frozen for further analysis.

To perform the analysis, colostrum samples were removed from the freezer and thawed in a water bath at $50{ }^{\circ} \mathrm{C}$, being homogenized during the thawing process, simulating the process adopted in farms. Samples at room temperature were used to estimate the Ig content with a colostrometer (Fleenor et al., 1980). From the total sample, aliquots were removed for microbiological evaluation and the remainder was lyophilized (Model Alpha 1-4/2-4 Ldplus - CHRIST - São Paulo, SP, Brazil) for evaluation of dry matter and nutrient contents. The determination of ether extract was performed by ether extraction using a Soxhlet extractor (AOAC, 1990). Samples of colostrum were also analyzed for total nitrogen by the Dumas method according to the methodology proposed by SaintDenis and Groupy (2004).

For microbiological analyses, dilution, plating, and microbial count methods were utilized as described by the Standard Methods for the Examination of Dairy Products (APHA, 1992). To prepare the dilutions, a $1.0-\mathrm{mL}$ aliquot was added to $9.0 \mathrm{~mL}$ of deionized sterile water in test tubes to obtain a dilution of $10^{-1}$. Next, $1 \mathrm{~mL}$ of a diluted solution at $10^{-1}$ plus $9.0 \mathrm{~mL}$ of sterile water were added to obtain a dilution of $10^{-2}$, and successive dilutions were performed to create the dilution needed for inoculation and microbial count. Enterobacteriaceae Petrifilm ${ }^{\circledR}$ plates $(3 \mathrm{M}$ do Brasil ${ }^{\circledR}$, Sumaré, SP, Brazil) were utilized to count the enterobacteria. Plates were inoculated with $1.0-\mathrm{mL}$ dilutions that were then prepared and incubated at $32.5 \pm 1{ }^{\circ} \mathrm{C}$ in BOD incubators, TE-402 model (Tecnal, Piracicaba, SP, Brazil), 
for $24 \pm 2 \mathrm{~h}$. After the incubation period, the microbial count was performed considering red colonies with a yellow zone and/or red colonies with gas bubbles, with or without yellow edges, as positive for enterobacteria. Petrifilm ${ }^{\circledR} \mathrm{AC}$ plates (3M do Brasil ${ }^{\circledR}$, Sumaré, SP, Brazil) were utilized to count the lactic acid bacteria, which were incubated in closed containers with an anaerobic atmosphere generator (ANAEROBAC, Probac do Brasil Produtos Bacteriológicos Ltda., São Paulo, SP, Brazil) and using the BOD incubator, TE-402 model (Tecnal, Piracicaba, SP, Brazil), at $32.5 \pm 1{ }^{\circ} \mathrm{C}$ for $48 \pm 3 \mathrm{~h}$. Red colonies were considered positive for lactic acid bacteria, independently of the color size or depth. To count yeasts and fungi, Petrifilm ${ }^{\circledR}$ YM plates (3M do Brasil $^{\circledR}$, Sumaré, SP, Brazil) were used and incubated at $22.5 \pm 1{ }^{\circ} \mathrm{C}$ while using a BOD incubator, TE-402 model (Tecnal, Piracicaba, SP, Brazil). The incubation lasted for $72 \mathrm{~h}$ and the number of small colonies with defined bluegreen edges were counted. Large and dark colonies with diffuse edges were counted after $120 \mathrm{~h}$ of incubation and were considered to be fungi colonies.

Data were summarized by simple descriptive statistics and grouped in tables while aiming to promote a better understanding, comparison, and discussion of results. The nutritional and microbiological compositions were analyzed through PROC GLM of SAS (Statistical Analysis System, version 9.0), considering the size and region of each farm, from which the colostrum was sampled, through the following statistical model: $\mathrm{Y}_{\mathrm{ij}}=\mu+\gamma_{\mathrm{i}}+\delta_{\mathrm{j}}+\mathrm{e}_{\mathrm{ij}}$, in which $Y_{i j}=$ response variable; $\mu=$ general mean; $\gamma_{i}=$ effect of total milk production; $\delta_{\mathrm{j}}=$ effect of region of property; and $\mathrm{e}_{\mathrm{ij}}=$ random effect (residue). Evaluation of the interaction between the total milk production and region of the property was not possible because the samples from the south region were obtained only from largesized properties. For the effect of mean comparison, a Student $t$ test was utilized and the means were estimated through the method of least squares with a significance level of $5 \%$. The correlation among variables for the nutritional and microbiological compositions were explored through PROC CORR of SAS.

\section{Results}

In properties with milk yields greater than $700 \mathrm{~L} / \mathrm{d}$, the contents of dry matter, crude protein, and Ig were higher than that of properties with milk yields lower than $200 \mathrm{~L} / \mathrm{d}$ or between 201 and $700 \mathrm{~L} / \mathrm{d}(\mathrm{P}<0.05)$. The average ether extract content was $5.59 \%$, though there was a large variation (5.20 to $6.25 \%$ ) (Table 2). The colostrum crude protein content was almost $6.5 \mathrm{pp}$ higher for properties with a milk production greater than $700 \mathrm{~L} / \mathrm{d}(\mathrm{P}<0.05)$, averaging $21.46 \%$ (Table 2). The average Ig concentration among colostrum samples was $51.72,48.06$, and $79.69 \mathrm{mg} / \mathrm{mL}$ for production systems with milk yields lower than $200 \mathrm{~L} / \mathrm{d}$, from 201 to $700 \mathrm{~L} / \mathrm{d}$, and greater than $700 \mathrm{~L} / \mathrm{d}$, respectively (Table 2). Immunoglobulin $\mathrm{G}$ concentration in colostrum samples were stratified as a function of the daily milk production of properties (Figure 1). In farms where the volume was lower than $200 \mathrm{~L} / \mathrm{d}$, almost $60 \%$ of colostrum samples were presented with Ig concentrations lower than $50 \mathrm{mg} / \mathrm{mL}$ $(\mathrm{P}<0.03)$, which is below literature recommendations for feeding newborn calves. On the other hand, in farms where the volume was greater than $701 \mathrm{~L} / \mathrm{d}$, only $28 \%$ of colostrum samples were below this recommendation, although other

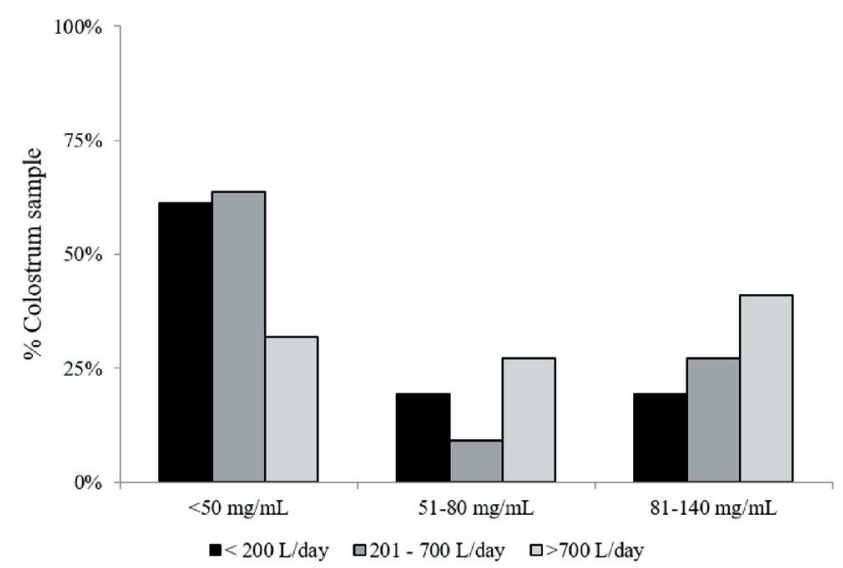

Figure 1 - Immunoglobulin concentration in colostrum samples from properties with different daily milk yields.

Table 2 - Nutritional composition and microbiological evaluation of colostrum samples as a function of daily milk yield

\begin{tabular}{lcccc}
\hline & $<200 \mathrm{~L}$ & 201 to $700 \mathrm{~L}$ & $>701 \mathrm{~L}$ & P-value \\
\hline Dry matter (DM; \%) & $22.6 \pm 1.35 \mathrm{~b}$ & $22.1 \pm 2.12 \mathrm{~b}$ & $27.3 \pm 1.26 \mathrm{a}$ & 0.04 \\
Ether extract (\% DM) & $5.2 \pm 0.90$ & $5.3 \pm 1.14$ & $6.2 \pm 0.85$ & 0.72 \\
Crude protein (\% DM) & $15.1 \pm 1.77 \mathrm{~b}$ & $15.2 \pm 2.78 \mathrm{~b}$ & $21.5 \pm 1.64 \mathrm{a}$ & 0.04 \\
Immunoglobulin (mg/mL) & $51.7 \pm 8.11 \mathrm{~b}$ & $48.1 \pm 11.90 \mathrm{~b}$ & $79.7 \pm 7.11 \mathrm{a}$ & 0.03 \\
Lactic acid bacteria (log 10) & $5.1 \pm 0.61$ & $4.5 \pm 0.95$ & $5.0 \pm 0.56$ & 0.86 \\
Enterobacteria (log 10) & $1.4 \pm 0.59 \mathrm{~b}$ & $1.6 \pm 0.93 \mathrm{~b}$ & $3.5 \pm 0.55 \mathrm{a}$ & 0.04 \\
Yeast (log 10) & $1.3 \pm 0.42$ & $1.7 \pm 0.66$ & $1.7 \pm 0.39$ & 0.69 \\
\hline
\end{tabular}

Means in the same row with different letters are different at $\mathrm{P}<0.05$. 
factors such as production system, animal breed, and time of cow milking can also affect the variables studied.

In regard to the microbiological characteristics of colostrum samples, there were no differences for the acid lactic bacteria count; however, the count of enterobacteria was greater in farms with the highest milk productions (Table 2). None of the colostrum samples presented fungi.

From the total samples that were analyzed, 47 and $76 \%$ presented characteristics recommended by the industry in relation to Ig concentration and microbial count, respectively (Figure 2). Some parameters of quality have a high correlation and can be utilized as practical methods for colostrum evaluation. For example, the estimate of Ig can be made through measurements of density. A positive correlation was observed between dry matter and crude protein contents, Ig and ether extract concentrations, as well as Ig concentration and crude protein content (Figure 3).

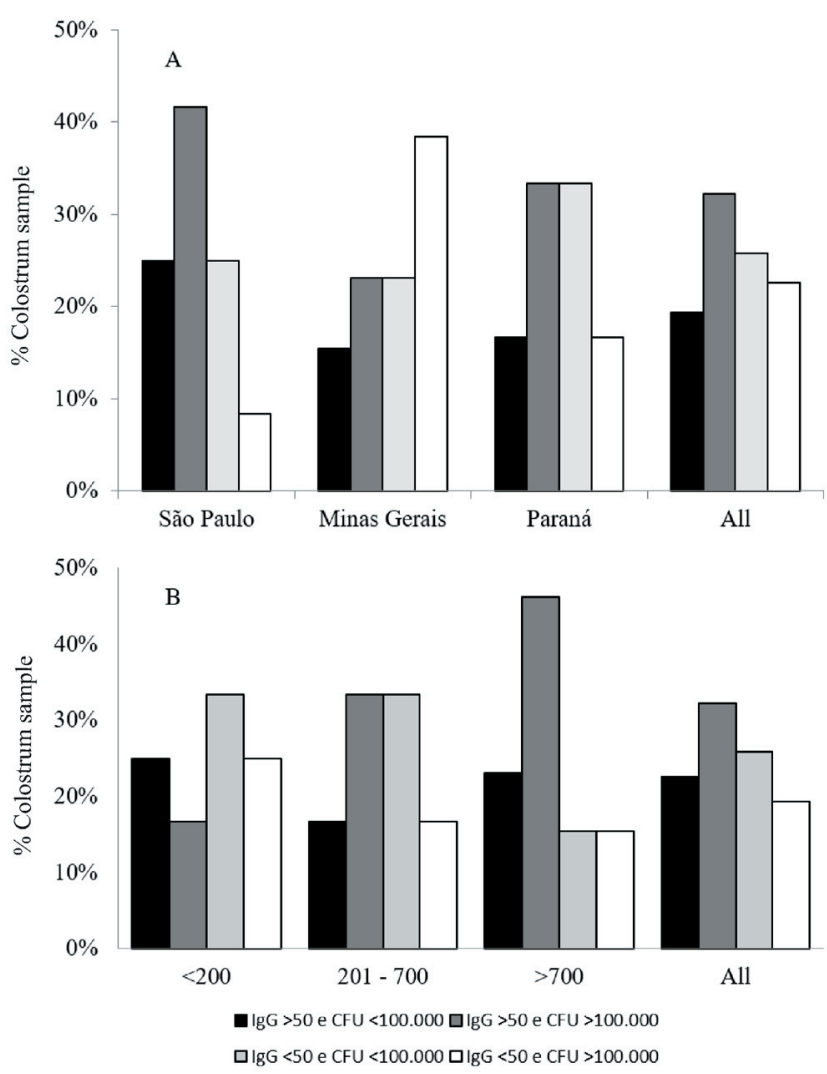

cfu - colony-forming unit; IgG - immunoglobulin G

Figure 2 - Nutritional and microbiological quality of colostrum samples as a function of regions of samples (A) and production scale $(\mathrm{B})$ of properties.

\section{Discussion}

Results suggest that there is a greater amount of newborn calves that are likely to have failure of passive immunity transfer in properties with total daily $\mathrm{MY}<700 \mathrm{~L} / \mathrm{d}$. Santos and Bittar (2015) characterized the production of calves in the same regions where colostrum was sampled and observed that in the majority of the small properties, dry and pregnant cows were raised without an adequate diet and in low-comfort and poor animal welfare conditions. These factors contribute to the differences, since feeding pregnant cows with restricted amount and poor-quality diets can compromise colostrum production (Weaver et al., 2000; Morin et al., 2001). According to Kehoe et al. (2007), the size of a dairy production system, which may be a confounding factor with total daily MY, influences the number of available workers, the financial capacity, and the feeding practices of cows, which then results in significant differences in terms of handling and colostrum composition.

Ether extract content influences the volume of produced colostrum, although few changes occur in the first five days after calving (Contarini et al., 2014). Previous studies showed that the ether extract concentration varied from 4.6 to $6.7 \%$ (Kehoe et al., 2007; Morril et al., 2012; Contarini et al., 2014) and similar values were observed in the present study. High-fat colostrum is desirable when there is a high demand for energy for the newborn, since calves are born with reduced energy reserves (Okamota et al., 1986) and have high energy requirements to maintain thermogenesis (Hammon et al., 2012).

Total protein and Ig contents were higher for farms with the highest total daily milk yield (Table 2). The average protein content of colostrum is represented mainly by $\mathrm{Ig}$, which has the important function of helping to combat microorganisms during the first days of life in a newborn calf (Weaver et al., 2000). Moreover, proteins from colostrum serve as a source of amino acids, although they can also play the role of meeting energy requirements (Talukder et al., 2002). Kehoe et al. (2007) found a protein content of $14.9 \%$ and emphasized that this component has little influence of feeding but more of parity of cows. In addition, Morril et al. (2012) observed a protein concentration of $12.7 \%$ without a significant difference between parity and breed in protein contents, factors not tested in the present study. The difference among protein contents can also be a function of the different methodologies of analyses, colostrum volume (Godden, 2008), and colostrum collection time after calving (Contarini et al., 2014). Colostrum presents higher total protein, mainly 
due to the high Ig contents, which decreases during the subsequent milkings, decreasing the total protein content until it stabilizes around 3.2\% (Tsioulpas et al., 2007).

The industry recommendation is that colostrum concentrations that are lower than $50 \mathrm{mg} \mathrm{IgG} / \mathrm{mL}$ should not be offered to newborns as their first feeding, as this increases the risk of failure of passive immunity transfer in calves (Donovan et al., 1998; Godden, 2008; Weaver, 2000). The average colostrum concentration in properties with milk yields between 201 and $700 \mathrm{~L} / \mathrm{d}$ is below the industry recommendation $(<50 \mathrm{mg} / \mathrm{mL})$. The lower concentration is probably due to the fact that samples were collected directly from the colostrum bank and these samples were not properly identified, and could have been taken from the 2nd, 3rd, or 4th milking without evaluation of the quality before storage. The fact is that these samples would probably be utilized to supply newborn calves when fresh cows do not produce colostrum in adequate quality, but mainly in volume, since there were no efforts to evaluate quality in these farms. Indeed, a survey conducted by Santos and Bittar (2015) at the same regions in Brazil, showed that $26 \%$ of the producers stored colostrum and only $7.4 \%$ of that measure quality using a colostrometer. However, other variables such as parity, breed, and colostrum collection time also contribute to these differences. The average value of Ig concentration $(59.8 \mathrm{mg} / \mathrm{mL})$ is below the average that was presented by Morril et al. (2012) for 827 samples in the United States and the value that was reported by
Bielmann et al. (2010) for 288 samples in Canada (69.7 and $94.4 \mathrm{mg} / \mathrm{mL}$ ); however, it is above the $34.9 \mathrm{mg} / \mathrm{mL}$ value, representing 55 samples from Kehoe et al. (2007) in the state of Pennsylvania, USA. Gulliksen et al. (2008) reported that most of the Norwegian cows produce colostrum with quality under the recommendations for feeding newborn calves. In a Brazilian study, Silper et al (2012) found an average Ig concentration of $77 \mathrm{mg} / \mathrm{dL}$, with a $32 \%$ coefficient of variation for different crossbreeding of Holstein cows.

Some factors probably contributed to the disparity in the values of Ig concentration according to the farm size. For example, the fact that the colostrum samples from larger properties had been collected from freezer-stored colostrum and should have received a previous evaluation of their quality prior to being stored. Another factor is the poorer handling of dry cows on small properties, since this group of animals was placed in low-quality paddocks without feed supplementation (Santos and Bittar, 2015), thereby negatively affecting colostrum formation.

Counts of lactic acid bacteria were not different among farms with different total daily milk yield (Table 2). Although this bacteria population is commonly found in milk products, as represented by Lactococcus, Streptococcus, and the Lactobacillus genera (Frank et al., 1992), temperature and inadequate storage conditions contribute to fast growth of these microorganisms. These results suggest good milking and freezer storage of colostrum for further
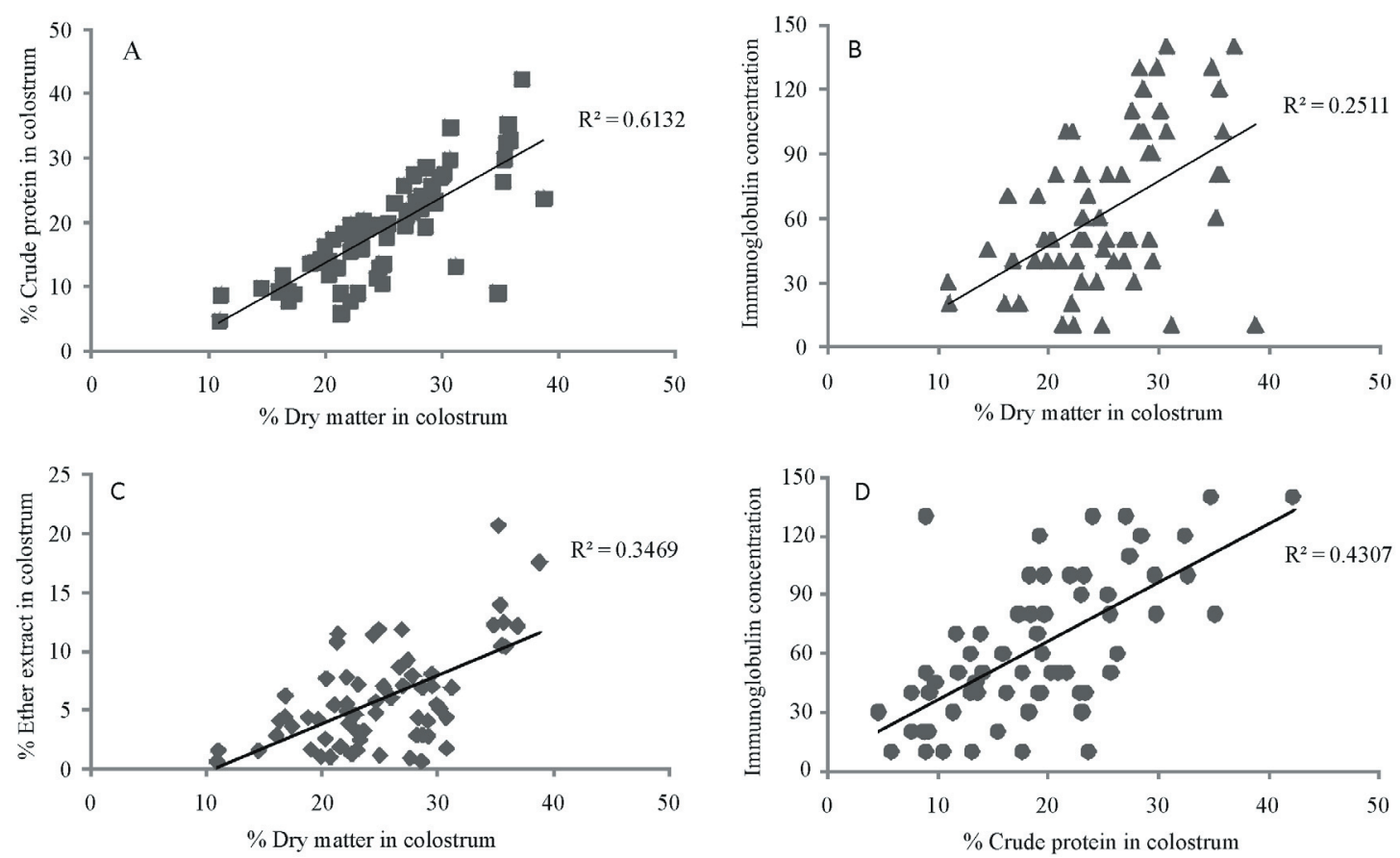

Figure 3 - Pearson correlation coefficient among the main variables studied 
feeding of newborn calves. The main damage caused by this group of bacteria is the degradation of lactose to obtain energy and the consequent $\mathrm{pH}$ reduction due to the lactic acid production (Wounters et al., 2002). However, in this group of bacteria, microorganisms with a probiotic function do exist and are beneficial to the host animal in that they improve intestinal microbial equilibrium through competitive exclusion, produce harmful metabolites to pathogenic bacteria, and play a role in the activation of the immune system (Seo et al., 2010).

On the other hand, the count of enterobacteria was greater $(\mathrm{P}<0.05)$ in colostrum samples from farms with milk production greater than $701 \mathrm{~L} / \mathrm{d}$. The main factor for development of bacteria from the Enterobacteria genus is the lack of hygiene before, during, and after colostrum milking (Stewart et al., 2005). In addition to the bacteria that degrade carbohydrates, bacteria such as Escherichia coli and Salmonella can be present, which are organisms responsible for causing diseases such as diarrhea. According to Quigley et al. (1994), there are several causes of diarrhea in calves such as a high bacterial load in the environment, failure of handling, and poor animal resistance. Thus, the supply of colostrum contaminated with diarrhea-causing microorganisms, while it does reduce the capacity of the animal to absorb IgG (James et al., 1981), also contributes to be the main cause of this disease. Therefore, even the performance of calves that receive adequate feeding, handling, and are raised under good welfare conditions can be affected. Thus, measurement of microbiological levels present in colostrum, as well as handling practices to avoid contamination and bacterial proliferation, become fundamental. According to the USDA-NAHMS (2007), $62 \%$ of deaths in milk-fed calves is caused by diarrhea and the supply of contaminated feedstuffs contributes to this high rate, as well as the exposure to a contaminated environment.

Colostrum should have adequate nutritional quality, as evaluated by $\mathrm{Ig}$ concentration $(>50 \mathrm{mg} / \mathrm{mL})$, and microbiological quality, determined as a function of low bacteria contamination $(<100.000 \mathrm{CFU} / \mathrm{mL})$, to be considered as acceptable to supply to newborn calves (Godden, 2008). When two quality variables were simultaneously analyzed, only $22.6 \%$ of all colostrum samples presented enterobacteria count below 100,000 $\mathrm{CFU} / \mathrm{mL}$ and $\mathrm{Ig}$ concentration higher than $50 \mathrm{mg} / \mathrm{mL}$ (Figure 2). Thus, $77.4 \%$ of calves in the studied regions are likely to suffer failure of passive immunity transfer. In the United States, Morrill et al. (2012) found that only $39.4 \%$ of 593 colostrum samples met both industry recommendations for colostrum quality. Such results are the evidence that more attention needs to be directed to management practices oriented towards cow handling in the last weeks before calving, as well as training and awareness of employees regarding the milking, storage, and supply of colostrum to feed newborn calves. There is a great difficulty in obtaining colostrum with adequate $\operatorname{IgG}$ concentrations associated with adequate microbiological quality at the recommended levels. This is relevant because the amount of variables that influence colostrogenesis is much greater than the hygienic aspects related to microbiological contamination (Stewart et al., 2005). Nevertheless, the concern of the farmer should be to meet these two quality issues simultaneously, due to their relevance for the newborn to acquire passive immunity and consequent health.

Almost half of the samples from farms where the milk yield was greater than $700 \mathrm{~L} / \mathrm{d}$ presented adequate Ig concentrations, although they were inadequate with regard to the microbiological parameters (Figure 2). When samples were separated by region, it was observed that in the São Paulo region, $40 \%$ of the samples presented an adequate Ig concentration; however, microbial contamination exceeded 100,000 CFU/mL. In the same manner, in Minas Gerais, almost $40 \%$ of colostrum samples had nutritional and microbiological qualities that did not fall within the industry recommendation. Thus, a large number of calves had problems due to the lack of hygienic care related to colostrum manipulation. All of these factors will negatively impact the cash flow of the milk production system through increases in the expenditure with health treatments and labor, increases in the duration of the pre and post-weaning phases, and increases in mortality (Faber et al., 2005; Godden, 2008).

Some quality parameters have a high correlation and can be utilized as practical methods for colostrum evaluation (Figure 3); these results correlate with data in the literature (Foley and Otterby, 1978; Davis and Drackely, 1998; Morin et al., 2001), which have reported a great influence of protein, mainly IgG, on the dry matter concentration of colostrum. Morin et al. (2001) found a correlation of $0.76(\mathrm{P}<0.0001)$ between the solid content and protein concentration and a slightly lower correlation with the IgG content $(\mathrm{r}=0.53, \mathrm{P}<0.0005)$. The authors explained that this greater correlation with protein is because there are other protein sources in colostrum besides IgG. The highest Pearson correlation was observed for dry matter (solids) and protein, corroborating the colostrometer method for colostrum quality evaluation, which is based on the colostrum density. 


\section{Conclusions}

Dairy calves born on farms with milk yield greater than 700 liters of milk per day are less susceptible to diseases during the first days of life due to the use of colostrum with a higher nutritional and microbiological quality.

\section{Acknowledgments}

The authors thank the São Paulo Research Foundation (Fapesp) for the financial support as scholarship (2012/ 17740-4).

\section{References}

AOAC - Association of Official Analytical Chemists. 1990. Official methods of analysis. 12th ed. AOAC, Washington, D.C.

APHA - American Public Health Association. 1992. Standard methods for the examination of water and wastewater. American Public Health Association; American Water Works Association; Water Environment Federation, Washington, D.C.

Bielmann, V.; Gillan, J.; Perkins, N. R.; Skidmore, A. L.; Godden, S. and Leslie, K. E. 2010. An evaluation of Brix refractometry instruments for measurement of colostrum quality in dairy cattle. Journal of Dairy Science 93:3713-3721.

Contarini, G.; Povolo, M.; Pelizzola, V.; Monti, L.; Bruni, A.; Passolungo, L.; Abeni, F. and Degano, L. 2014. Bovine colostrum: Changes in lipid constituents in the first 5 days after parturition. Journal of Dairy Science 97:5065-5072.

Davis, C. L. and Drackley, J. K. 1998. The development, nutrition, and management of the young calf. Iowa State University Press, Ames.

DeNise, S. K.; Robison, J. D. and Scott, G. H. 1989. Effects of passive immunity on subsequent production in dairy heifers. Journal of Dairy Science 72:552-554.

Donovan, G. A.; Dohoo, I. R. and Montgomery, D. M. 1998. Associations between passive immunity and morbidity and mortality in dairy heifers in Florida, USA. Previne Veterinarian Medicine 34:31-46.

Faber, S. N.; Faber, N. E. and McCauley, T. C. 2005. Effects of colostrum ingestion on lactational performance. Professional Animal Science 21:420-425.

Fleenor, W. A. and Stott, G. H. 1980. Hydrometer test for estimation of immunoglobulin concentration in bovine colostrum. Journal of Dairy Science 63:973-977.

Foley, J. A. and Otterby, D. E. 1978. Availability, storage, treatment, composition, and feeding value of surplus colostrum: A review. Journal of Dairy Science 61:1033-1060.

Frank, J. F.; Christen, G. L. and Bullerman, L. B. 1992. Tests of groups of microorganisms. p.271-286. In: Standard methods for the examination of dairy products. Marshall, R. T., ed. American Public Health Association, Washington.

Godden, S. 2008. Colostrum management for dairy calves. Veterinary Clinics of North America: Food Animal Practice 24:19-39.

Gulliksen, S. M.; Lie, K. I.; Sølverød, L. and Østera, O. S. 2008. Risk factors associated with colostrum quality in Norwegian dairy cows. Journal of Dairy Science 91:704-712

Hammon, H. M.; Steinhoff-Wagner, J.; Schonhusen, U.; Metges, C. C. and Blum, J. W. 2012. Energy metabolism in the newborn farm animal with emphasis on the calf: Endocrine changes and responses to milk-born and systemic hormones. Domestic Animal Endocrinology 43:171-185.

James, R. E. and Polan, C. E. 1978. Effect of orally administered duodenal fluid on serum proteins in neonatal calves. Journal of Dairy Science 61:1444-1449.

James, R. E.; Polan, C. E. and Cummins, K. A. 1981. Influence of administered indigenous microorganisms on uptake of [iodine125] $\gamma$-globulin in vivo by intestinal segments of neonatal calves. Journal of Dairy Science 64:52-61.

Kehoe, S. I.; Jayarao, B. M. and Heinrichs, A. J. 2007. A survey of bovine colostrum composition and colostrum management practices on Pennsylvania dairy farms. Journal of Dairy Science 90:4108-4116.

Morin, D. E.; Constable, P. D.; Maunsell, F. P. and McCoy, G. C. 2001. Factors associated with colostral specific gravity in dairy cows. Journal of Dairy Science 84:937-943.

Morrill, K. M.; Conrad, E.; Lago, A.; Campbell, J.; Quigley, J. and Tyler, H. 2012. Nationwide evaluation of quality and composition of colostrum on dairy farms in the United States. Journal of Dairy Science 95:3997-4005.

USDA-NAHMS Dairy 2007, Part I: Reference of dairy cattle health and management practices in the United States. USDA, Washington, DC. 2007. Available at: <http://www.aphis.usda. gov/animal_health/nahms/dairy/\#dairy2007>. Accessed on: July 18, 2013.

NRC - National Research Council. 2001. Nutrient requirements of dairy cattle. 7th rev. ed. Natl. Acad. Sci., Washington, DC.

Okamota, M.; Robinson, J. B.; Christopherson, R. J. and Young, B. A. 1986. Summit metabolism of newborn calves with and without colostrum feeding. Canandian Journal Animal Science 66:937-944.

Quigley, J. D.; Martin, K. R.; Dowlen, H. H.; Wallis, L. B. and Lamar, K. 1994. Immunoglobulin concentration, specific gravity, and nitrogen fractions of colostrum from Jersey cattle. Journal of Dairy Science 77:264-269.

Saint-Denis, T. and Groupy, J. 2004. Optimization of a nitrogen analyzer based on the Dumas method. Analytica Chimica Acta 515:191-198.

Santos, G. and Bittar, C. M. M. 2015. A survey of dairy calf management practices in some producing regions in Brazil. Revista Brasileira de Zootecnia 44:361-370.

Seo, J. K.; Kim, S. W.; Kim, M. H.; Upadhaya, S. D.; Kam, D. K. and Ha, J. K. 2010. Direct-fed microbials for ruminant animals. AsianAustralasian Journal of Animal Sciences 23:1657-1667.

Silper, B. F; Coelho, S. G.; Madeira, M. M. F.; Ruas, J. R. M.; Lana, A. M. Q.; Reis, R. B. and Saturnino, H. M. 2012. Avaliação da qualidade do colostro e transferência de imunidade passiva em animais mestiços Holandês Zebu. Arquivo Brasileiro de Medicina Veterinária e Zootecnia 64:281-285.

Stabel, J. R.; Hurd, S.; Calvente, L. and Rosenbusch, R. F. 2004. Destruction of Mycobacterium paratuberculosis, Salmonella spp., and Mycoplasma spp. in raw milk by a commercial on-farm high temperature, short-time pasteurizer. Journal of Dairy Science $87: 2177-2183$.

Stewart, S.; Godden, S.; Bey, R.; Rapnicki, P.; Fetrow, J.; Farnsworth, R.; ScanloN, M.; Arnold, Y. and Ferrouillet, C. 2005. Preventing bacterial contamination and proliferation during the harvest, storage, and feeding of fresh bovine colostrum. Journal of Dairy Science 88:1584-1599.

Talukder, M. J. R.; Takeuchi, T. and Harada, E. 2002. Transport of Colostral Macromolecules into the Cerebrospinal Fluid via Plasma in Newborn Calves. Journal of Dairy Science 85:1789-1803. 
Tsioulpas, A.; Grandison, A. D. and Lewis, M. J. 2007. Changes in physical properties of bovine milk from the colostrum period to early lactation. Journal of Dairy Science 90:5012-5017.

Weaver, D. M.; Tyler, J. W.; Van Metre, D. C. and Barrington, G. M. 2000. Passive transfer of colostral immunoglobulins in calves. Journal Veterinary Internal Medicine 14:569-577.
Wells, S. J.; Dargatz, D. A. and Ott, S. L. 1996. Factors associated with mortality to 21 days of life in dairy heifers in the United States. Preventive Veterinarian Medicine 29:9-19.

Wouters, J. T. M.; Ayad, E. H. E.; Hugenholtz, J. and Smit, G. 2002. Microbes from raw milk for fermented dairy products. International Dairy Journal 12:91-109. 